\title{
A Study of Different Biochemical and Sonological Parameters as Predictors of Preeclampsia
}

\author{
Jhantu Kumar Saha', Palash Mazumder², Prithu Bandyopadhyay³, Shyamali Datta4 \\ ${ }^{1}$ Department of Obstetrics and Gynaecology, Medical College, Kolkata, West Bengal, India. ${ }^{2}$ Department of Obstetrics \\ and Gynaecology, Medical College, Kolkata, West Bengal, India. ${ }^{3}$ Department of Obstetrics and Gynaecology, Medical \\ College, Kolkata, West Bengal, India. ${ }^{4}$ Department of Obstetrics and Gynaecology, Medical College, Kolkata, West \\ Bengal, India.
}

\section{ABSTRACT}

\section{BACKGROUND}

Preeclampsia-eclampsia is a very common cause of maternal \& perinatal mortality \& morbidity. Predictors of preeclampsia in apparently healthy pregnant patients by some biochemical \& sonological parameter, either individually or in combination may be helpful.

\section{METHODS}

This is an OPD based prospective study at medical college, Kolkata, dept. of G \& 0 from $1^{\text {st }}$ January 2013 to 30 th June 2014. Singleton normotensive patients at 12-14 wks. gestation were included in the study. Patients with chronic hypertension, multifetal pregnancy, heart disease, renal disease \& diabetes mellitus were excluded. Serum parameters AFP, bHCG, inhibin A, urinary parameters like urinary calcium-creatinine ratio (spot sample), sonological parameters like uterine artery doppler study, RI, PI, notching were measured.

\section{RESULTS}

15 out of a total of 200 patients (7.5\%) developed preeclampsia. Booking BMI \& Uristix protein had significant association with preeclampsia. Among the biochemical \& sonological markers maternal serum bHCG, uterine artery doppler RI (22-24 wks.) \& notching (22-24 wks.) had the best sensitivity, specificity \& predictive value. The combination of high maternal serum bHCG combined with persistent notching or high RI at 22-24 wks. uterine artery doppler had the highest specificity \& predictive value for prevalence of development of preeclampsia.

\section{CONCLUSIONS}

Thus, those women with high $\beta$-hCG ( $>2.499$ MOM) and either high RI $(>0.625)$ or persistent notching in 22-24 weeks uterine artery Doppler scan should be followed up more intensively as they are at significantly high risk of developing preeclampsia.

\section{KEY WORDS}

Preeclampsia, Prediction, Serum Biochemical Marker, Beta HCG, Doppler Velocimetry
Corresponding Author: Dr. Palash Mazumder, Akshara Lotus Garden, Block 3, Flat 1A, F/F2,

Hatiara Road, Kolkata, West Bengal, India.

E-mail: drpalash2011@gmail.com

DOI: $10.14260 /$ jemds/2019/829

Financial or Other Competing Interests: None.

How to Cite This Article:

Saha JK, Mazumder P, Bandyopadhyay, et al. A study of different biochemical and sonological parameters as predictors of preeclampsia. J. Evolution Med. Dent. Sci. 2019;8(51):3825-3829, DOI: 10.14260/jemds/2019/829

Submission 16-10-2019,

Peer Review 04-12-2019,

Acceptance 10-12-2019,

Published 23-12-2019. 


\section{BACKGROUND}

Sometimes, pregnancy and childbirth are complicated by some unique disorders like preeclampsia \& eclampsia that lead to significant morbidity and even mortality world wide ${ }^{1,2}$ in certain situations. Preeclampsia/Eclampsia causes approx. $1 / 4^{\text {th }}$ of all maternal deaths in India (MMR-178 in 2010-12). ${ }^{3}$ Preeclampsia is defined as new onset hypertension $\geq 140 / 90$ $\mathrm{mm} \mathrm{Hg}$ after 20 weeks of pregnancy with proteinuria $\geq 300$ $\mathrm{mg} / 24$ hours or $\geq 1+$ dipstick (NHBPEP), ${ }^{4}$ (ISSHP). ${ }^{5}$ This disorder complicates $2-8 \%$ of all pregnancies.6,7, Early diagnosis and intensive management of at risk patients may improve both maternal and foetal outcome.

Recent understanding of aetiology and pathogenesis of preeclampsia has identified a two-stage model; poor placentation and oxidative stress \& inflammation. ${ }^{9}$ Dysfunction of trophoblastic cells in preeclampsia leads to increased level of AFP, bHCG \& Inhibin A in maternal serum. Failure of trophoblastic invasion into the maternal spiral arteries, can be investigated by uterine artery doppler velocimetry at around 20 wks. of gestation. Persistence of increased resistance to uterine arterial flow indicates increased risk of preeclampsia.10 Decreased excretion of calcium in urine of asymptomatic patients will eventually help to develop preeclampsia.11,12 The calcium-creatinine ratio in urine is reduced in these women. A simple spot urine calcium-creatinine ratio in $2^{\text {nd }}$ trimester may detect such patients. ${ }^{13,14}$

We wanted to analyse the potential clinical use of these biochemical parameters (serum $\beta$-hCG, AFP, Inhibin-A, urine calcium-creatinine ratio) and sonological parameters (uterine artery doppler) individually and also in combination for the purpose of prediction of preeclampsia.

\section{METHODS}

The institutional ethics committee of Medical College, Kolkata has approved the study on 9.2.2013 after checking the required protocol. While undertaking the study voluntary informed consent was taken from each patient in writing (Bengali/ Hindi /English) \& full confidentiality of the patients had been retained.

This was an OPD based prospective study. Sample technique was purposive sampling, a type of non-probability sampling, performed at Medical College Hospital, Kolkata, Department of Obstetrics and Gynaecology from $1^{\text {st }}$ June 2013 to $30^{\text {th }}$ June 2014. Singleton normotensive women attending antenatal clinic (OPD) at 12-14 weeks of gestation are included in the study. Antenatal women with chronic hypertension, multifoetal pregnancy, heart disease, renal disease \& diabetes mellitus are excluded from the study. Data were collected from all eligible candidates with informed consent. Two hundred (200) patients had been investigated during the study process and were followed up till delivery. Sample size determination in this study was based on the cost, time \& convenience of collecting the data \& the need for it to offer sufficient statistical power. Detailed history was taken and examination of pregnant mothers at 12-14 weeks of gestation were done.
Uterine artery doppler study was done at 12-14 weeks \& repeated at 22-24 wks. of gestation. Maternal serum markers i.e. $\beta$-hCG, AFP, Inhibin- $A^{15}$ were done between 12 and 16 weeks of gestation by ELISA technique. Urine examination was done for calcium creatinine ratio (calcium by ocresolphthalein complex reaction ${ }^{16}$ and creatinine by Jaffes method) ${ }^{17}$ at 20-24 weeks of gestation. We selected the spot test over 24-hour sample for the sake of feasibility.

How many of patients developed preeclampsia were seen and sensitivity, specificity and predictive values of each biochemical \& sonological parameters were calculated in isolation and in combination-

- The statistical software SPSS version 20 \& Microsoft excel 2013 has been used for the analysis.

- An alpha level of $5 \%$ has been taken, i.e. if any $\mathrm{p}$ value is less than 0.05 it has been considered as significant.

- Categorical variables are expressed as number \& percentage of patie.

- Presence and absence of Preeclampsia is compared across different categorical variables using Pearson's Chi Square test for Independence of Attributes.

- Continuous variables are expressed as Mean \pm Standard Deviation and compared across the 2 groups (developed and not developed preeclampsia) using unpaired t test.

- ROC (receiver operating characteristic) curve analysis is done to establish the cut offs for MOM of selected biochemical \& sonological parameters. Cut offs were determined by finding the specific value of each parameter for which the sum of sensitivity and specificity is highest.

\section{RESULTS}

Table 1 shows the incidence of preeclampsia in the study population $(\mathrm{n}=200)$ is 15 , which is $7.5 \%$ Chart 1 \& Table 2 shows the cut off values of the different biochemical and sonological parameters as determined from the analysis of the ROC curves $\&$ also the comparison of different parameters with development of preeclampsia. Among the 39 subjects whose MOM AFP was high i.e. above cut off, 10 developed preeclampsia, 5 subjects among 161 developed preeclampsia yet their MOM AFP level was normal. Among the 40 subjects whose MOM $\beta$-hCG was high i.e. above cut off, 12 developed preeclampsia, 3 subjects among 160 developed preeclampsia yet their MOM $\beta$-hCG level was normal.

Among the 51 subjects whose MOM inhibin-A was high i.e. above cut off, 11 developed preeclampsia, 4 subjects among 149 developed preeclampsia yet their MOM inhibin-A level was normal. Among the 60 subjects whose doppler RI (12-14 wks.) was high i.e. above cut off, 12 developed preeclampsia, 3 subjects among 140 developed preeclampsia yet their doppler RI (12-14 wks.) level was normal. Among the 129 subjects whose doppler PI (12-14 wks.) was high i.e. above cut off, 12 developed preeclampsia, 3 subjects among 71 developed preeclampsia yet their doppler PI (12-14 wks.) level was normal. Among the 48 subjects whose doppler RI (22-24 wks.) was high i.e. above cut off, 12 developed preeclampsia, 3 subjects among 152 developed preeclampsia yet their doppler RI (22-24 wks.) level was normal. 
Among the 72 subjects whose doppler PI (22-24 wks.) was high i.e. above cut off, 11 developed preeclampsia, 4 subjects among 128 developed preeclampsia yet their doppler PI (22-24 wks.) level was normal. Among the 50 subjects whose CCR (20-24 wks.) was high i.e. above cut off, 10 developed preeclampsia, 5 subjects among 150 developed preeclampsia yet their CCR (20-24 wks.) level was normal. Among the 50 subjects who had notching in doppler (22-24 wks.), 12 developed preeclampsia. 3 subjects among the 150 did not have notching in doppler (22-24 wks.) yet they did develop preeclampsia. Table 3 shows the sensitivity, specificity and predictive value of each parameter used for prediction of preeclampsia. Tests with best sensitivity, specificity and predictive value are MS $\beta$-hCG, doppler RI (2224 weeks) and doppler notching (22-24 weeks). Highest PPV and specificity MS hCG $30.0 \%$ and $84.86 \%$, lowest PPV and specificity PI (12-14 wks.) 9.3\% and 36.76\%.

These 3 parameters are taken together for analysis to find the combined sensitivity, specificity and predictive values for various combinations of them. criteria used-

1. Any 1 of the 3 , positive then positive ('or' criteria)

That is when either of hCG or RI (22-24 weeks) or notching (22-24 weeks) is positive.

2. Any 2 of the 3 , positive then positive ('and' criteria)

That is when any two of hCG, RI (22-24 weeks), notching (22-24 weeks) is positive together.

3. All 3 of 3 positive then positive ('and' criteria)

That is when all of hCG and RI (22-24 weeks) and notching (22-24 weeks) are positive together.

\begin{tabular}{|c|c|c|}
\hline Preeclampsia & Frequency & Percent \\
\hline Not Developed & 185 & 92.5 \\
\hline Developed & 15 & 7.5 \\
\hline Total & $\mathbf{2 0 0}$ & $\mathbf{1 0 0 . 0}$ \\
\hline Table 1. Incidence of Preeclampsia in the Study Population \\
\hline
\end{tabular}

\begin{tabular}{|c|c|c|c|c|c|c|c|}
\hline \multirow{2}{*}{$\begin{array}{l}\dot{z} \\
\dot{\omega}\end{array}$} & \multirow{2}{*}{ 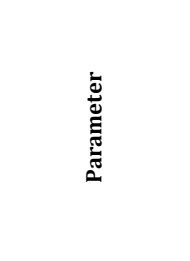 } & \multirow{2}{*}{ 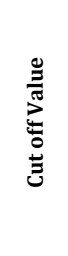 } & \multirow{2}{*}{ 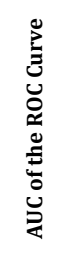 } & \multicolumn{2}{|c|}{ 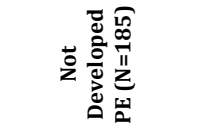 } & \multicolumn{2}{|c|}{ 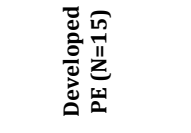 } \\
\hline & & & & 勇 & 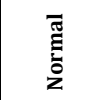 & 홍 & $\begin{array}{l}\text { 吾 } \\
\text { ż }\end{array}$ \\
\hline 1 & MOM MS AFP & 2.158 & 0.753 & $\begin{array}{c}29 \\
(74.36 \%) \\
\end{array}$ & $\begin{array}{c}156 \\
(96.89 \%) \\
\end{array}$ & \begin{tabular}{|c|}
10 \\
$(25.64 \%)$ \\
\end{tabular} & \begin{tabular}{|c|}
5 \\
$(3.11 \%)$ \\
\end{tabular} \\
\hline 2 & MOM MS $\beta$ HCG & 2.499 & 0.857 & $\begin{array}{c}28 \\
(70 \%) \\
\end{array}$ & \begin{tabular}{|c|}
157 \\
$(98.13 \%)$ \\
\end{tabular} & $\begin{array}{c}12 \\
(30 \%)\end{array}$ & \begin{tabular}{|c|}
03 \\
$(1.87 \%)$ \\
\end{tabular} \\
\hline 3 & MOM MS Inhibin A & 2.454 & 0.784 & $\begin{array}{c}40 \\
(78.43 \%)\end{array}$ & $\begin{array}{c}145 \\
(97.32 \%)\end{array}$ & \begin{tabular}{c|c|}
11 \\
$(21.57 \%)$
\end{tabular} & $\begin{array}{c}4 \\
(2.68 \%) \\
\end{array}$ \\
\hline 4 & $\begin{array}{c}\text { Doppler RI } \\
(12-14 \text { wks.) }\end{array}$ & 1.605 & 0.805 & $\begin{array}{c}48 \\
(80 \%) \\
\end{array}$ & \begin{tabular}{|c|c|}
137 \\
$(97.86 \%)$ \\
\end{tabular} & $\begin{array}{c}12 \\
(20 \%) \\
\end{array}$ & \begin{tabular}{|c|}
3 \\
$(2.14 \%)$ \\
\end{tabular} \\
\hline 5 & $\begin{array}{c}\text { Doppler PI } \\
(12-14 \text { wks.) }\end{array}$ & 1.775 & 0.545 & $\begin{array}{c}117 \\
(90.7 \%) \\
\end{array}$ & \begin{tabular}{|c|}
68 \\
$(95.67 \%)$ \\
\end{tabular} & $\begin{array}{c}12 \\
(9.3 \%) \\
\end{array}$ & $\begin{array}{c}3 \\
(4.33 \%) \\
\end{array}$ \\
\hline 6 & $\begin{array}{c}\text { Doppler RI } \\
(22-24 \text { wks.) }\end{array}$ & 0.625 & 0.625 & $\begin{array}{c}36 \\
(75 \%) \\
\end{array}$ & \begin{tabular}{|c|}
149 \\
$(98.03 \%)$ \\
\end{tabular} & $\begin{array}{c}12 \\
(25 \%) \\
\end{array}$ & \begin{tabular}{|c|}
3 \\
$(1.97 \%)$ \\
\end{tabular} \\
\hline 7 & $\begin{array}{c}\text { Doppler PI } \\
(22-24 \text { wks.) }\end{array}$ & 1.93 & 0.659 & $\begin{array}{c}61 \\
(84.72 \%) \\
\end{array}$ & $\begin{array}{c}124 \\
(96.88 \%) \\
\end{array}$ & \begin{tabular}{|c|}
14 \\
$(15.28 \%)$ \\
\end{tabular} & $\begin{array}{c}1 \\
(3.12 \%) \\
\end{array}$ \\
\hline 8 & $\begin{array}{c}\text { CCR } \\
(20-24 \text { wks.) }\end{array}$ & 0.11 & 0.258 & $\begin{array}{c}40 \\
(80 \%) \\
\end{array}$ & \begin{tabular}{|c|}
145 \\
$(96.67 \%)$ \\
\end{tabular} & $\begin{array}{c}10 \\
(20 \%) \\
\end{array}$ & \begin{tabular}{|c|}
5 \\
$(3.33 \%)$ \\
\end{tabular} \\
\hline 9 & $\begin{array}{r}\text { Notching in } \\
(22-24 \\
\end{array}$ & $\begin{array}{l}\text { ppler } \\
\text { s.) }\end{array}$ & & $\begin{array}{l}\text { Yes: } 38 \\
(76 \%)\end{array}$ & $\begin{array}{c}\text { No: } 147 \\
(98 \%) \\
\end{array}$ & $\begin{array}{l}\text { Yes: } 12 \\
(24 \%)\end{array}$ & $\begin{array}{l}\text { No: } 3 \\
(2 \%)\end{array}$ \\
\hline
\end{tabular}

Table 4 shows the comparison of different tests; when any 1 of 3 tests, either 2 of the 3 tests and all 3 tests are abnormal. Among the 76 subjects who had either of the 3 tests abnormal 14 developed preeclampsia. Mong 124 of those who had all tests normal developed preeclampsia.
Among the 17 subjects who had (hCG + RI) \& (hCG + notching) tests abnormal, 10 developed preeclampsia. 5 among 183 of those who had normal tests developed preeclampsia. Among the 45 subjects who had (RI + notching) tests abnormal 12 developed preeclampsia. 3 among 155 of those who had normal tests developed preeclampsia. Among the 17 subjects who had all the tests abnormal 10 developed preeclampsia. Table 5 shows the sensitivity, specificity and predictive value of the combined tests. Among them, when either of the 3 tests were positive sensitivity of prediction of preeclampsia improved significantly (93.33\%) but at the cost of specificity and PPV (66.49\% and $18.42 \%$ ). Combination of hCG with RI and hCG with notching yielded specificity $96.22 \%$, PPV 58.82\%; so did combination of all three tests. For combination of RI and notching specificity was $82.16 \%$ and PPV $26.67 \%$.

\begin{tabular}{|c|c|c|c|c|c|c|c|c|}
\hline Parameter & TP & TN & FP & FN & $\begin{array}{c}\text { Sensiti- } \\
\text { vity }\end{array}$ & $\begin{array}{c}\text { Specifi- } \\
\text { city }\end{array}$ & PPV & NPV \\
\hline $\begin{array}{c}\text { MOM MS AFP (ng/mL) } \\
\text { (12-16 weeks) }\end{array}$ & 10 & 156 & 29 & 5 & 66.67 & 84.32 & 25.64 & 96.89 \\
\hline $\begin{array}{c}\text { MOM MS } \beta \text {-hCG (IU/mL) } \\
\text { (12-16 weeks) }\end{array}$ & 12 & 157 & 28 & 3 & 80.00 & 84.86 & 30.00 & 98.13 \\
\hline $\begin{array}{c}\text { MOM MS Inhibin- } \\
\text { A(pg/mL) } \\
(12-16 \text { weeks) }\end{array}$ & 11 & 145 & 40 & 4 & 73.33 & 78.38 & 21.57 & 97.32 \\
\hline $\begin{array}{c}\text { RI uterine artery Doppler } \\
\text { (12-14 weeks) }\end{array}$ & 12 & 137 & 48 & 3 & 80.00 & 74.05 & 20.00 & 97.86 \\
\hline $\begin{array}{c}\text { PI uterine artery Doppler } \\
(12-14 \text { weeks) }\end{array}$ & 12 & 68 & 117 & 3 & 80.00 & 36.76 & 9.30 & 95.77 \\
\hline $\begin{array}{c}\text { RI uterine artery Doppler } \\
\text { (22-24 weeks) }\end{array}$ & 12 & 149 & 36 & 3 & 80.00 & 80.54 & 25.00 & 98.03 \\
\hline $\begin{array}{c}\text { PI uterine artery Doppler } \\
\text { (22-24 weeks) }\end{array}$ & 11 & 124 & 61 & 4 & 73.33 & 67.03 & 15.28 & 96.88 \\
\hline $\begin{array}{c}\text { Urine calcium-creatinine } \\
\text { ratio (20-24 weeks) }\end{array}$ & 10 & 145 & 40 & 5 & 66.67 & 78.38 & 20.00 & 96.67 \\
\hline $\begin{array}{c}\text { Notching } \\
\text { (22-24 weeks) }\end{array}$ & 12 & 147 & 38 & 3 & 80.00 & 79.46 & 24.00 & 98.00 \\
\hline $\begin{array}{c}\text { Table 3. Sensitivity, Specificity and Predictive Values of Individual } \\
\text { Parameters in Prediction of Development of Preeclampsia }\end{array}$ \\
\hline
\end{tabular}

\begin{tabular}{|c|c|c|c|c|c|c|c|}
\hline \multirow{3}{*}{$\begin{array}{c}\text { Sl. } \\
\text { No. }\end{array}$} & \multirow{3}{*}{ Parameter } & \multicolumn{6}{|c|}{ Developed PE } \\
\hline & & \multicolumn{3}{|c|}{ No } & \multicolumn{3}{|c|}{ Yes } \\
\hline & & Normal & $\begin{array}{c}\text { Ab- } \\
\text { normal }\end{array}$ & Total & Normal & \begin{tabular}{|c|} 
Ab- \\
normal
\end{tabular} & Tota \\
\hline 1. & $\begin{array}{l}\text { hCG/RI/notching } \\
\text { (1 of } 3 \text { abnormal) }\end{array}$ & $\begin{array}{c}123 \\
(99.19 \%) \\
\end{array}$ & $\begin{array}{c}62 \\
(81.58 \%) \\
\end{array}$ & 185 & $\begin{array}{c}1 \\
(0.81 \%) \\
\end{array}$ & \begin{tabular}{|c|}
14 \\
$(18.42 \%)$ \\
\end{tabular} & 15 \\
\hline 2. & hCG+ RI & \begin{tabular}{|c|}
178 \\
$(97.27 \%)$ \\
\end{tabular} & $\begin{array}{c}7 \\
(41.18 \%) \\
\end{array}$ & 185 & $\begin{array}{c}5 \\
(2.73 \%) \\
\end{array}$ & \begin{tabular}{|c|}
10 \\
$(58.82 \%)$ \\
\end{tabular} & 15 \\
\hline 3. & hCG + notching & \begin{tabular}{|c|}
178 \\
$(97.27 \%)$ \\
\end{tabular} & $\begin{array}{c}7 \\
(41.18 \%) \\
\end{array}$ & 185 & $\begin{array}{c}5 \\
(2.73 \%) \\
\end{array}$ & \begin{tabular}{|c|}
10 \\
$(58.82 \%)$ \\
\end{tabular} & 15 \\
\hline 4. & RI + notching & $\begin{array}{c}152 \\
(98.06 \%) \\
\end{array}$ & $\begin{array}{c}33 \\
(73.33 \%) \\
\end{array}$ & 185 & $\begin{array}{c}3 \\
(1.94 \%) \\
\end{array}$ & \begin{tabular}{|c|}
12 \\
$(26,67 \%)$ \\
\end{tabular} & 15 \\
\hline 5. & $\begin{array}{l}\mathrm{hCG}+\mathrm{RI}+\text { notching } \\
\text { (all } 3 \text { abnormal) }\end{array}$ & $\begin{array}{c}178 \\
(97.27 \%) \\
\end{array}$ & $\begin{array}{c}7 \\
(41.18 \%) \\
\end{array}$ & 185 & $\begin{array}{c}5 \\
(2.73 \%) \\
\end{array}$ & \begin{tabular}{c|}
10 \\
$(58.82 \%)$ \\
\end{tabular} & 15 \\
\hline \multicolumn{8}{|c|}{$\begin{array}{c}\text { Table 4. Comparison of Different Tests; When Any } 1 \text { of } 3 \text { Tests, } \\
\text { either } 2 \text { of the } 3 \text { Tests and all } 3 \text { Tests are Abnormal }\end{array}$} \\
\hline
\end{tabular}

\begin{tabular}{|c|c|c|c|c|c|c|c|c|}
\hline $\begin{array}{c}\text { Scoring } \\
\text { System }\end{array}$ & TP & TN & FP & FN & $\begin{array}{c}\text { Sensiti- } \\
\text { vity }\end{array}$ & $\begin{array}{c}\text { Specifi- } \\
\text { city }\end{array}$ & PPV & NPV \\
\hline $\begin{array}{c}\text { hCG/RI/ } \\
\text { notching }\end{array}$ & $\begin{array}{c}14 \\
(18.42 \%)\end{array}$ & $\begin{array}{c}123 \\
(99.1 \%)\end{array}$ & $\begin{array}{c}62 \\
(81.58 \%)\end{array}$ & $\begin{array}{c}1 \\
(0.81 \%)\end{array}$ & 93.33 & 66.49 & 18.42 & 99.19 \\
\hline hCG + RI & $\begin{array}{c}10 \\
(58.82 \%)\end{array}$ & $\begin{array}{c}178 \\
(97.27 \%)\end{array}$ & $\begin{array}{c}7 \\
(41.18 \%)\end{array}$ & $\begin{array}{c}5 \\
(2.73 \%)\end{array}$ & 66.67 & 96.22 & 58.82 & 97.27 \\
\hline $\begin{array}{c}\text { hCG + } \\
\text { notching }\end{array}$ & $\begin{array}{c}10 \\
(58.82 \%)\end{array}$ & $\begin{array}{c}178 \\
(97.27 \%)\end{array}$ & $\begin{array}{c}7 \\
(41.18 \%)\end{array}$ & $\begin{array}{c}5 \\
(2.73 \%)\end{array}$ & 66.67 & 96.22 & 58.82 & 97.27 \\
\hline $\begin{array}{c}\mathrm{RI}+ \\
\text { notching }\end{array}$ & $\begin{array}{c}12 \\
(26.67 \%)\end{array}$ & $\begin{array}{c}152 \\
(98.06 \%)\end{array}$ & $\begin{array}{c}33 \\
(73.33 \%)\end{array}$ & $3(1.94 \%)$ & 80.00 & 82.16 & 26.67 & 98.06 \\
\hline $\begin{array}{c}\text { hCG + RI + } \\
\text { notching }\end{array}$ & $\begin{array}{c}10 \\
(58.82 \%)\end{array}$ & $\begin{array}{c}178 \\
(97.27 \%)\end{array}$ & $7(41.18 \%)$ & $\begin{array}{c}5 \\
(2.73 \%)\end{array}$ & 66.67 & 96.22 & 58.82 & 97.27 \\
\hline Table 5. Sensitivity, Specificity and Predictive Value of the Combinations \\
\hline
\end{tabular}

Table 6 shows the comparison of mean of the continuous variables of the tests for prediction of preeclampsia. All the comparisons were significant $(\mathrm{p}<0.05)$ with development of preeclampsia except PI of uterine artery Doppler (12-14 weeks) (2.05 vs $1.98, \mathrm{p}=0.546)$. Thus, uterine artery doppler 
RI, notching at $22-24$ weeks and serum $\beta$-hCG are the tests that best predicted development of preeclampsia individually. Combination of $\beta$-hCG with any of the doppler parameters is more specific and has better predictive value than each test alone. Addition of all three tests does not increase the specificity.

\begin{tabular}{|c|c|c|c|c|}
\hline & \multicolumn{2}{|c|}{ Developed Preeclampsia } & \multirow{3}{*}{$\mathbf{p}$} & \multirow{3}{*}{$\begin{array}{l}\text { Signifi- } \\
\text { cance }\end{array}$} \\
\hline & No & Yes & & \\
\hline & Mean \pm S.D. & Mean \pm S.D. & & \\
\hline $\begin{array}{l}\text { MOM AFP (ng/mL) } \\
(12-16 \text { weeks })\end{array}$ & $1.48 \pm 0.61$ & $2.05 \pm 0.63$ & 0.001 & Significant \\
\hline $\begin{array}{c}\text { MOM } \beta \text {-hCG }(\mathrm{IU} / \mathrm{mL}) \\
(12-16 \text { weeks) }\end{array}$ & $1.59 \pm 0.69$ & $2.73 \pm 0.8$ & $<0.001$ & Significant \\
\hline $\begin{array}{c}\text { MOM Inhibin-A(pg/mL) } \\
(12-16 \text { weeks })\end{array}$ & $1.7 \pm 0.7$ & $2.48 \pm 0.68$ & $<0.001$ & Significant \\
\hline $\begin{array}{c}\text { RI uterine artery Doppler } \\
(12-14 \text { weeks })\end{array}$ & $0.56 \pm 0.06$ & $0.63 \pm 0.05$ & $<0.001$ & Significant \\
\hline $\begin{array}{c}\text { PI uterine artery Doppler } \\
(12-14 \text { weeks })\end{array}$ & $1.98 \pm 0.4$ & $2.05 \pm 0.35$ & 0.546 & $\begin{array}{c}\text { Not } \\
\text { Significant }\end{array}$ \\
\hline $\begin{array}{c}\text { RI uterine artery Doppler } \\
(22-24 \text { weeks })\end{array}$ & $0.54 \pm 0.07$ & $0.62 \pm 0.08$ & $<0.001$ & Significant \\
\hline $\begin{array}{c}\text { PI uterine artery Doppler } \\
(22-24 \text { weeks })\end{array}$ & $1.83 \pm 0.39$ & $2.07 \pm 0.54$ & 0.029 & Significant \\
\hline $\begin{array}{l}\text { Urine calcium-creatinine } \\
\text { ratio (20-24 weeks) }\end{array}$ & $0.14 \pm 0.03$ & $0.11 \pm 0.03$ & $<0.001$ & Significant \\
\hline
\end{tabular}

Table 6. Comparison of Mean of the Continuous Variables of the Different Tests

\section{DISCUSSION}

There is no screening test for preeclampsia (WHO metaanalysis by Conde-Agudelo and associates in 200418). Basic theme of various predictive tests including the present one for preeclampsia is to identify a specific pathogenic process that can be detected sufficiently early in asymptomatic stage that will prevent the development of preeclampsia syndrome. Analysis of the results showed- 15 of the total 200 patients developed preeclampsia. Thus, incidence was $7.5 \%$. Consistent with previous studies, that stated incidence of 2 $8 \% .6,7,8$

Serum parameters done between 12-16 weeks of pregnancy yielded the following data: MS AFP was found raised above the cut off (cut off $2.158 \mathrm{MOM}$ ) in 39 subjects; of them 10 subjects developed preeclampsia. MS $\beta$-hCG was found raised above cut off (cut off 2.499 MOM) in 40 subjects; of them 12 subjects developed preeclampsia. MS inhibin-A was found raised above cut off (cut off 2.454 MOM) in 51 cases among them 11 subjects developed preeclampsia. Comparison of mean of MOM of these parameters showed significant association with development of preeclampsia (2.05 vs 1.48 for AFP $p=0.001,2.73$ vs 1.59 for $\beta$-hCG $\mathrm{p}<0.001,2.48$ vs 1.7 for inhibin-A $\mathrm{p}<0.001$ ).

Study by Aquilina et $\mathrm{al}^{19}$ used $\beta$-hCG and inhibin-A (cut off $>2.0 \mathrm{MOM}$ ) and found sensitivity of Inhibin-A to be greater than hCG (48.6\% vs $37.4 \%)$ fixing specificity at $90 \%(\mathrm{p}<0.05)$ for preeclampsia prediction. Yaron et al ${ }^{20}$ found significant association with preeclampsia and other adverse pregnancy outcomes when $\beta$-hCG and AFP were $>2.5$ MOM $(\mathrm{p}<0.001)$. Our study found significant association with all the serum parameters namely $\beta$-hCG, AFP and inhibin-A and preeclampsia, consistent with previous studies. Uterine artery Doppler was performed twice in our study, first at 12 14 weeks and again at 22-24 weeks for RI, PI and notching (in 22-24 weeks scan). RI of uterine artery (12-14 weeks) was raised above cut off value of 0.605 in 60 cases, out of them 12 subjects developed preeclampsia whereas at 22-24 wks. it was raised above cut off value of 1.775 in 129 cases, out of them 12 developed preeclampsia. PI of uterine artery (12-14 weeks) was raised above cut off value of 1.775 in 129 cases, out of them 12 developed preeclampsia whereas at 22-24 wks. it was raised above cut off value of 1.775 in 129 cases, out of them 12 developed preeclampsia.

Notching in 22-24 weeks was present in 40 subjects out of them 12 subjects developed preeclampsia. Comparison of mean of these variables showed significant association with all the parameters with development of preeclampsia, except PI at $12-14$ weeks ( 0.63 vs 0.56 for RI $12-14$ weeks, $p<0.001$; 0.62 vs 0.54 for RI $22-24$ weeks, $p<0.001$ and 2.07 vs 1.83 for PI 22-24 weeks, $p=0.029$ ). First and second trimester uterine artery Doppler have been tested by several authors for significance in preeclampsia prediction. Papageorgieu et $\mathrm{al}^{21,22}$ found persistence of high impedance pattern in uterine artery in $2^{\text {nd }}$ trimester to significantly increase likelihood of preeclampsia (LR of 6 vs 5) These reports are consistent with our present study since we also found $2^{\text {nd }}$ trimester Doppler indices to be more sensitive and specific for preeclampsia prediction. Urine calcium-creatinine ratio was done by a spot test between 20-24 weeks. CCR was below the cut off value of 0.11 in 50 cases, out of them 10 subjects developed preeclampsia

Comparison of mean showed significant relation between CCR and development of preeclampsia (0.11 vs 0.14 , $\mathrm{p}<0.001$ ). Studies by Ozcan et $\mathrm{al}^{23}$ (using cut off 0.066), Saudan et $\mathrm{al}^{24}$, Izumi et $\mathrm{al}^{18}$ (both using cut off 0.10 ) all found significant association of CCR in $1^{\text {st }}$ or $2^{\text {nd }}$ trimester with development of preeclampsia. Sensitivity and specificity of these studies ranged between $70-80 \%$ and $75-85 \%$ respectively, which is consistent with our current study. There was one $(0.5 \%)$ case of severe preeclampsia that had all the parameters above the cut-off levels. There were 2 (1\%) patients who delivered at 34 weeks and 8 (4\%) patients who delivered at 36 weeks. All others were followed for more than 37 weeks of pregnancy. No patients had eclamptic convulsions. Thus, individually the tests that best predicted preeclampsia was MS $\beta$-hCG, uterine artery Doppler RI at 2224 weeks and diastolic notching in uterine artery Doppler at 22-24 weeks. The combination of $\beta$-hCG (12-16 weeks) with $\mathrm{RI} /$ notching at 22-24 weeks appears to be the best panel for combination of tests for prediction of preeclampsia. A combination of all three tests does not yield higher predictive value than any of the two described above. However, a larger multicentric study is needed to establish their positive correlation and implement the same for predicting preeclampsia in practice.

\section{CONCLUSIONS}

Maternal serum $\beta$-hCG and uterine artery Doppler $\mathrm{RI} /$ notching (22-24 weeks) is the best combination of predictive tests for preeclampsia. Individually ms $\beta$-hCG (1216 weeks), uterine artery Doppler RI (22-24 weeks) and uterine artery Doppler notching (22-24 weeks) are the tests having best sensitivity, specificity and predictive values for prediction of preeclampsia. All the other serum parameters (AFP, inhibin A), urine parameters (CCR) and sonological parameters (except Doppler PI 12-14 weeks) are significantly 
associated with development of preeclampsia. Thus, those women with high $\beta$-hCG ( $>2.499$ MOM) and either high RI $(>0.625)$ or persistent notching in 22-24 weeks uterine artery Doppler scan should be followed up more intensively as they are at significantly high risk of developing preeclampsia.

\section{ACKNOWLEDGEMENT}

Authors thank Prof. Partha Mukhopadhay, HOD (G\&O), Eden Hospital, Medical College and Prof T. K. Lahiri, Principal, Medical College, Kolkata, Chairman, Institutional Ethics Committee, Medical College.

\section{REFERENCES}

[1] Why mothers die, 2000-2002, Royal College of Obstetricians and Gynaecologists, CEMACH, London: RCOG, 2004

[2] UNICEF, The progress of nations 2001, New York: United Nations Childrens' Fund, 2011.

[3] Third special bulletin on Maternal Mortality Ratio (20102012), Office of the Registrar General, India. 20 ${ }^{\text {th }}$ December 2013.

[4] Report of the National High Blood Pressure Education Program working group on high blood pressure in pregnancy. Am J Obstet Gynecol 2000;183(1):S1-S22.

[5] Brown MA, Lindheimer MD, de Swiet M, et al. The classification and diagnosis of the hypertensive disorders of pregnancy: statement from the International Society for the study of Hypertension in Pregnancy (ISSHP). Hypertens Pregnancy 2001;20(1):914.

[6] Sibai BM. Diagnosis and management of gestational hypertension and preeclampsia. Obstet Gynecol 2003;102(1):181-92.

[7] Hauth JC, Ewell MG, Levine RL, et al. Pregnancy outcomes in healthy nulliparous women who subsequently developed hypertension. Calcium for Preeclampsia Prevention Study Group. Obstet Gynecol 2000;95(1):248.

[8] WHO: World Health Report 2005: make every mother and child count. Geneva: WHO 2005: p. 63.

[9] Redman CW, Sargent IL. Placental stress and preeclampsia: a revised view. Placenta 2009;30(Suppl A):S38-S42.

[10] Chien PF, Arnott N, Gordon A, et al. How useful is uterine artery Doppler flow velocimetry in the prediction of preeclampsia, intrauterine growth retardation and perinatal death? An overview. BJOG 2000;107(2):196-208.
[11] Tolaymat A, Sanchez-Ramos L, Yergey AL, et al. Physiology of hypocalciuria in pre-eclampsia: measurement of intestinal calcium absorption. Obstet Gynecol 1994;83(2):239-43.

[12] Belizan JM, Villar J, Gonzalez L, et al. Calcium supplementation to prevent hypertensive disorders of pregnancy. N Engl J Med 1991;325(20):1399-405.

[13] Izumi A, Minakami H, Kuwata T, et al. Calcium-tocreatinine ratio in spot urine samples in early pregnancy and its relation to the development of preeclampsia. Metabolism 1997;46(10):1107-8.

[14] Kazerooni T, Hamze-Nejadi S. Calcium to creatinine ratio in a spot sample of urine for early predection of preeclampsia. Int J Gynaecol Obstet 2003;80(3):279-83.

[15] Colorimetric enzyme immunoassay, Streptavidin Biotin based sandwich assay, $\beta \mathrm{hCG}$ and AFP Accubind ELISA kit, Monobind inc. Lake Forest, CA 92630, USA.

[16] Morin LG. Direct colorimetric determination of serum calcium with o-cresolphthalein complexone. Am J Clin Pathol 1974;61(1):114-7.

[17] Greenwald I. The chemistry of Jaffe's reaction for creatinine II. The effect of substitution in the creatinine molecule and a possible formula for the red tautomer. Journal of the American Chemical Society 1925;47(5):1443-8.

[18] Conde-Agudelo A, Villar J, Lindheimer M. World Health Organization systematic review of screening tests for preeclampsia. Obstet Gynecol 2004;104(6):1367-91.

[19] Aquilina J, Maplethorpe R, Ellis P, et al. Correlation between second trimester maternal serum inhibin-A and human chorionic gonadotrophin for the prediction of preeclampsia. Placenta 2000;21(5-6):487-92.

[20] Yaron Y, Cherry M, Kramer RL, et al. Second trimester maternal serum marker screening: maternal serum AFP, $\beta$-hCG, estriol and their various combinations as predictors of pregnancy outcome. Am J Obstet Gynecol 1999;181(4):968-74.

[21] Papageorghiou AT, Yu CK, Nicolaides KH. The role of uterine artery Doppler in predicting adverse pregnancy outcome. Best Pract Res Clin Obstet Gyn 2004;18(3):383-96.

[22] Papageorghiou AT, Yu CKH, Bindra R, et al. Multicentre screening for preeclampsia and fetal growth restriction by transvaginal uterine artery Doppler at 23 weeks of gestation. Ultrasound Obstet Gynecol 2001;18(5):441-9.

[23] Ozcan T, Kaleli B, Ozeren M, et al. Urinary calcium to creatinine ratio for predicting preeclampsia. Am J Perinatol 1995;12(5):349-51.

[24] Saudan PJ, Shaw L, Brown MA. Urinary calcium/creatinine ratio as a predictor of preeclampsia. Am J Hypertens 1998;11(7):839-43. 